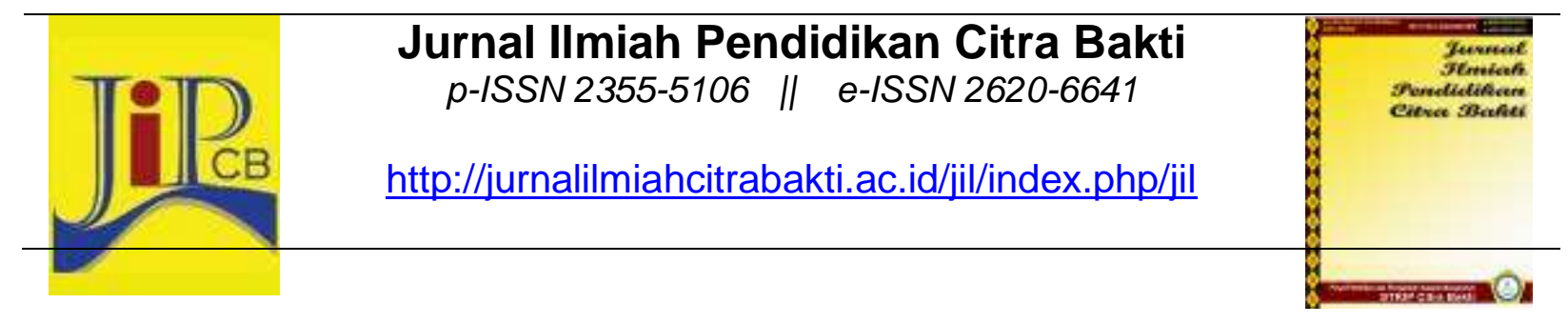

\title{
KEEFEKTIFAN MODEL MIND MAPPING TERHADAP KEMAMPUAN MENULIS TEKS ANEKDOT SISWA SMA
}

\author{
Ahmad $^{1)}$ dan Gamar Abdul Nasir ${ }^{2}$ \\ ${ }^{1,2)}$ Program Studi Pendidikan Bahasa dan Sastra Indonesia, Universitas Muhammadiyah \\ Kupang \\ ${ }^{1)}$ pinrangahmad89@gmail.com, 2)gamar@unmuh-kupang.ac.id
}

\begin{abstract}
Histori artikel
Received:

7 September 2020

Accepted:

20 Oktober 2020

Published:

1 November 2020

Abstrak

Tujuan dari penelitian ini adalah mendeskripsikan keefektifan model mind mapping terhadap kemampuan menulis teks anekdot siswa SMA. Penelitian ini menggunakan desain eksprimen murni. Jumlah siswa yang menjadi subjek yaitu 148 orang di kelas $X$ SMA Muhammadiyah Kupang tahun ajaran 2019/2020. Untuk Kelas kontrol yaitu kelas $\mathrm{X}_{1}$ dan Kelas $\mathrm{X}_{2}$ sebagai kelas ekprimen, penentuan sampel menggunakan random sampling. Tes uraian yang digunakan sebagai Instrumen dalam penelitian ini untuk memperoleh data. Berlandaskan hasil kajian inferensial memakai uji-t. Nilai $\mathrm{T}_{\text {hitung }} 30,541>1,66600$, kesimpulannya $\mathrm{H}_{0}$ ditolak dan $\mathrm{H}_{1}$ diterima. Untuk kelas kontrol pada posstest nilai minimum yaitu 2,28 dan nilai maksimum 3,00 atau rata-rata 2,65 . Untuk kelas eksprimen nilai minimum 2,57 dan nilai maksimum 3,57 atau ratarata 3,05. Data tersebut didapatkan pada kajian statistik deskriptif dan inferensial uji-t. Jadi, menulis teks anekdot memakai model mind mapping adalah efektif meningkatkan kemampuan menulis siswa.
\end{abstract}

Kata kata kunci: menulis teks anekdot, model mind mapping 
Abstract. This pure experiment research aimed at describing the effectiveness of mind mapping model towards anecdote text writing abilities on senior high school students. The subject of this study were 148 students of tenth grade students at SMA Muhammadiyah Kupang 2019/2020 academic year. The random sampling was used in this study with $X_{1}$ grade as the control class and $X_{2}$ grade as the experiment class. The study used descriptive test to know the students' anecdote writing abilities and was analyzed by using descriptive statistics and inferential statistics $t$-test. The result of posttest in control class obtained the maximum score 3.00 and the minimum score was 2.28 with the average score 2.65, while in the experiment class, the maximum score was 3.57 and the minimum score was 2.57 with the average score 3.05 . Based on the results of inferential analysis by using $t$-test, the score of $\mathrm{t}$-count was $30.541>1.66600$, so $\mathrm{H}_{0}$ was rejected and $\mathrm{H}_{1}$ was accepted. Therefore, mind mapping model was effective to increase the students' writing abilities.

Keywords: writing anecdote text, mind mapping model

\section{Latar Belakang}

Keterampilan menulis identik dengan teks sehingga tidak bisa lepas dari penelaan bahasa Indonesia. Adapun beberapa jenis teks yakni teks anekdot, teks biografi, teks narasi, teks deskripsi, teks negosiasi, teks biografi dan sebagainya. Namun, peneliti hanya akan membahas teks anekdot sebab dalam proses pembelajaran teks anekdot diperlukan siswa dengan perhatian yang lebih saat pembelajaran. Secara tersurat dalam kurikulum 2013 teks anekdot adalah teks yang diajarkan dalam mata kajian bahasa Indonesia.

Berlandaskan hasil pengamatan dan dengar pendapat bersama guru bahasa Indonesia yang menerapkan kurikulum 2013 diperoleh keterangan bahwa kegiatan pembelajaran menulis kelas $X$ dengan jumlah 148 siswa masih sulit dilakukan. Hal ini, diketahui 19\% siswa mampu menulis teks anekdot, tetapi sulit menentukan struktur teks anekdot, dan $61 \%$ siswa kesulitan menulis dan menentukan struktur teks anekdot. Kesulitan ini disebabkan oleh kendala yang didapatkan di sekolah. Kendala tersebut yaitu menentukan tema dan menentukan struktur teks menjadi teks anekdot, struktur teks yang dimaksud antara lain koda, orientasi, krisis, abstraksi, dan reaksi, kendala lain, pemilihan kata, penyampaian gagasan dan menentukan topik atau gagasan yang biasanya tersendat, kemudian sulit mengembangkan humor. Siswa diharapkan mampu menuangkan konsep secara runut dan sistematis untuk memberikan informasi dan menambah wawasan bagi penikmat dan menghidupkan suasana (Sunimbar et al., 2019).

Buzan pada tahun 1975 menemukan model mind mapping untuk memberi solusi yang dialami siswa dalam menulis teks anekdot. Yusrumaida (Irma, Syamsuri, \& Arief 2020) siswa dapat meningkatkan kemampuan menulis dengan menggunkan teknik mind mapping. Deporter dan Hernacki (Saharah \& Indihadi, 2019) menjelaskan, teknik mencatat secara menyeluruh dalam satu halaman disebut mind mapping atau peta pikiran. Menurut Hartati (Saharah \& Indihadi, 2019) dalam pembelajaran menulis permulaan dan menulis lanjut itu layaknya pembelajaran membaca. Dalman (Susilowati, 2019) menggunakan bahasa tulis sebagai alat atau media penyampaian pesan secara tertulis dapat dikatakan suatu kegiatan komunikasi. Boner (Situmorang, 2018) juga menulis dalam bukunya menjelaskan beberapa 
langkah dalam menulis menggunakan pertanyaan. Berikut adalah langkah-langkahnya. (1) Pikirkan tentang subjek tulisan. Subjek dalam hal ini dapat berarti orang, masalah, kejadian, ide, isu, atau apapun topik yang akan dikembangkan menjadi sebuah tulisan. (2) Jawab pertanyaan - pertanyaan tentang subjek. Mulai menjawab pertanyaan-pertanyaan tentang subjek dari pertanyaan pertama sampai seluruh pertanyaan terjawab (3) Buat daftar jawaban sebagai tuntunan teks yang akan dituliskan. Pendapat lain, Akhadiah (Ramadhanti, 2017) menyatakan bahwa keterampilan kompleks adalah keterampilan menulis.

Mahsun (Susilowati, 2019) teks membentuk bahasa yang berfungsi melakukan pekerjaan spesifik latarbelakang kedudukan. Keraf (Sholekah \& Nuryatim, 2017) seseorang menuangkan yang menarik atau aneh semacam cerita pendek dapat dikatakan teks anekdot. Tetapi ada pendapat lain yang dikemukan oleh Chaer (Sholekah \& Nuryatim, 2017) mengemukakan tokoh dalam anekdot bukan tokoh fiktif, melainkan tokoh nyata yang ada dalam sejarah baik cerita singkat yang humor dan mengenai orang tekenal yang nyata dan pernah ada dapat juga dikatakan anekdot.

Pardiyono (Sholekah \& Nuryatim, 2017) mamaklumatkan struktur teks anekdot (1) pernyataan (topik dituangkan dalam judul); (2) orientasi, pendahuluan; (3) kekonyolan kejadian yang menimpa atau dialami; (4) akibat, dan (5) koda, bagian akhir dari teks anekdot. Fatimah (Toibah, 2019) pengalaman pribadi sesorang yang menggambarkan kritik tidak langsung, baik sindiran, senda gurau, percakapan lucu dengan berbagai tujuan disebut juga teks anekdot.

Shoimin (Syam \& Ramlah, 2015) mengemukakan pengertian peta pikiran bahwa: pemetaan pikiran untuk membentuk kesan dengan teknik pemanfaatan citra visual dan prasarana grafis. Pendapat lain keutamaan dari penelaahan peta pikiran dikemukakan oleh Swadarma (Syam \& Ramlah, 2015) yakni: a) memajukan prestasi pengetahuan; b) mengoptimalkan kemampuan otak; c) saling bekerjasama mengembangkan ide dan informasi; d) meningkatkan inspirasi, dan e) gampang digunakan.

Model pembelajaran mind mapping adalah alternatif membantu siswa memperoleh penelaahan yang berkesan dan menarik (Sunimbar et al., 2019). Penelaahan siswa dengan memanfaatkan mind mapping dapat meluaskan wawasan dan inovatif bernalar bagi siswa serta tidak membuat jenuh dalam menerima materi secara menyeluruh, kemudian siswa juga belajar lebih praktis, dan mampu membuktikan draf, hakikat, dan langkah-langkah. Mind mapping mempermudah siswa dalam mencatat materi pembelajaran dengan kreatif karena biasa menambahkan berbagai macam bentuk diksi sehingga siswa mudah mengingat materi (Cahya et al., 2019), selanjut Menurut Buzan (Syam \& Ramlah, 2015) bahwa mind maping (peta pikiran) ini akan membantu anak, mudah mengingat sesuatu, mengingat fakta, angka, 
dan rumus dengan mudah, meningkatkan motivasi dan konsentrasi, mengingat dan menghafal menjadi lebih cepat.

Tujuan penelitian yaitu memerikan keterampilan menulis teks anekdot dengan memanfaatkan model langsung siswa Kelas X SMA Muhammadiyah Kupang, memerikan keterampilan menulis teks anekdot dengan menerapkan model pembelajaran mind mapping siswa kelas $\mathrm{X}$ dan mendemontrasikan keberhasilan model pembelajaran mind mapping keterampilan menulis teks anekdot siswa kelas X SMA Muhammadiyah Kupang.

\section{Metode}

Menggunakan desain Posttest Only Control Design dengan memanfaatkan eksprimen murni Jumlah siswa menjadi subjek yaitu 148 orang di kelas X SMA Muhammadiyah Kupang Tahun Ajaran 2019/2020. Untuk Kelas kontrol yaitu kelas $X_{1}$ dan Kelas $\mathrm{X}_{2}$ sebagai kelas eksprimen, penentuan sampel menggunakan random sampling.

\begin{tabular}{ccc}
\hline \multicolumn{2}{c}{ Rancangan tersebut dapat digambarkan sebagai berikut } \\
\hline $\mathbf{R}$ & $\mathbf{X}$ & $\mathbf{O}_{1}$ \\
\hline $\mathbf{R}$ & $\mathbf{O}_{2}$ \\
\hline
\end{tabular}

Keterangan:

$\mathrm{R}=$ kelas eksperimen dan kelas kontrol

$\mathrm{X} \quad=$ Perlakuan

$\mathrm{O}_{1}=$ Posteest kelas eksprimen

$\mathrm{O} 2=$ Posteest kelas kontrol

(Sugiyono, 2008:112)

Untuk memperoleh data penelitian, teknik yang digunakan adalah teknik tes bertujuan memperoleh data keterampilan menulis teks anekdot berlandaskan struktur teks. Selanjutnya, hasil kerja atau tes siswa diolah menggunakan kajian statistik deskriptif yaitu data dideskripsikan dalam bentuk tabel dengan membuat daftar skor mentah, distribusi frekuensi dari skor mentah, menghitung nilai rata-rata, dan menentukan perbandingan nilai rata-rata kelas kontrol dan eksprimen. Sedangkan statistik inferensial digunakan untuk menguji hipotesis dengan menggunakan uji-t, tetapi sebelum melakukan pengujian hipotesis, terlebih dahulu dilakukan uji normalitas dan homogenitas, data tersebut berasal dari kelas $\mathrm{X}_{1}$ kelas kontrol dan $\mathrm{X}_{2}$ kelas eksprimen, untuk kelas kontrol tidak diberikan perlakuan atau siswa hanya diberikan pembelajaran dengan menggunakan model langsung, sedangkan kelas eksprimen diberikan pelakuan dengan menggunakan model mind mapping. Selanjutnya instrumen yang digunakan mengumpulkan data adalah treatmen, tes (pos-tes), untuk mengungkap data kemampuan siswa dalam menulis teks anekdot yang dilakukan oleh 
siswa kelas X SMA Muhammadiyah Kupang, data yang digunakan adalaha hasil tes. Berdasarkan jumlah populasi cukup banyak yaitu 148 siswa, maka peneliti menetapkan sampel dari jumlah populasi yaitu dua kelas, dengan pengambilan sampel menggunakan teknik acak (random sampling) dengan ketentuan kemampuan siswa yang sama (homogen).

Kaiian ini diaplikasikan pada bulan Februari tahun 2020. Penelitian dilakukan di SMA Muhammadiyah Kupang yang beralamat di Jln. Ahmad Dahlan, Kota Kupang dengan mempertimbangkan kelender pendidikan di SMA Muhammadiyah Kupang tahun 2019/2020.

\section{Hasil dan Pembahasan}

\section{Hasil}

Pengutaraan nilai siswa memekai kajian statistik deskriptif dan Inferensial (uji normalitas, homogenitas, dan uji-t program SPSS) pada kelas kontrol dan eksprimen. Berikut penjabarannya:

Keterampilan Menulis Teks Anekdot menggunakan model langsung

Tabel 1. Postes Penerapan Model Langsung

\begin{tabular}{cccc}
\hline Nilai & Frekuensi & Persentase & Persentase Komulatif \\
\hline 2.28 & 4 & 10.0 & 10.8 \\
2.35 & 1 & 2.5 & 13.5 \\
2.42 & 1 & 2.5 & 16.2 \\
2.49 & 7 & 17.5 & 35.1 \\
2.56 & 1 & 2.5 & 37.8 \\
2.57 & 3 & 7.5 & 45.9 \\
2.64 & 1 & 2.5 & 48.6 \\
2.71 & 5 & 12.5 & 62.2 \\
2.78 & 4 & 10.0 & 73.0 \\
2.85 & 1 & 2.5 & 75.7 \\
2.92 & 4 & 10.0 & 86.5 \\
2.99 & 3 & 7.5 & 94.6 \\
3.00 & 2 & 5.0 & 100.0 \\
Total & 37 & 100 & \\
\hline
\end{tabular}

Berlandaskan pada Tabel 1 total 37 siswa, yaitu belum ada siswa yang memperoleh nilai maksimal 4. Nilai maksimal diperoleh adalah 3,00 yang didapatkan dua anak (5,0\%), nilai minimum didapatkan 2,28 yang didapatkan empat anak atau (10.0\%). Ringkasan karekteristik pembagian nilai yang didapatkan siswa dilihat tabel berikut. 


\section{Tabel 2. Distribusi Nilai Menggunakan Model Langsung}

\begin{tabular}{lll}
\hline \multirow{2}{*}{$N$} & \multicolumn{1}{c}{ Valid } & \multicolumn{1}{c}{37} \\
\cline { 2 - 3 } & Missing & \multicolumn{1}{c}{3} \\
\hline Mean & 2.6595 \\
Std. Error of Mean & .03780 \\
Median & 2.7100 \\
Mode & 2.49 \\
Std. Deviation & .22990 \\
Variance & .053 \\
Range & .72 \\
Minimum & 2.28 \\
Maximum & 3.00 \\
Sum & 98.40 \\
\hline
\end{tabular}

Berdasarkan Tabel 2 tersebut diketahui 37 siswa yang di tes, nilai maksimum yang didapatkan 3,00. Selanjutnya nilai minimum didapatkan anak 2,28; nilai mean adalah 2,65; nilai tengah adalah 2,71 dan standar deviasi adalah 0,22990. Berlandaskan karakter nilai tersebut dapat dinyatakan kategorisasi nilai keterampilan menulis teks anekdot anekdot kelas $\mathrm{X}_{1}$ SMA Muhammadiyah Kupang menggunakan model langsung pada kelas kontrol. Apabila nilai ketuntasan keterampilan menulis teks anekdot siswa dikonversi ke KKM, dapat diamati di tabel klasifikasi tingkat ketuntasan peserta didik berikut:

Tabel 3. Klasifikasi Tingkat Ketuntasan Kemampuan Menulis Menggunakan Model Langsung

\begin{tabular}{cccc}
\hline Nilai & Frekuensi & Persentase (\%) & Kategori \\
\hline Nilai 2,66 ke atas & 19 & 51,3 & Tuntas \\
Nilai di bawah 2,66 & 18 & 48,7 & Tidak Tuntas \\
\hline
\end{tabular}

Berlandaskan Tabel 3 tersebut, siswa yang mendapat nilai 2,66 ke atas sebanyak 19 siswa $(51,3 \%)$ dan yang mendapat nilai 2,66 ke bawah berjumlah 18 siswa $(48,7 \%)$, dapat dinyatakan ketuntasan tanpa aplikasi model mind mapping pada kelas kontrol tidak efektif.

Keterampilan Menulis Teks Anekdot Menggunakan Model Mind Mapping

Tabel 4 Postes Penerapan Model Mind Mapping

\begin{tabular}{cccc}
\hline Nilai & Frekuensi & Persentase & Persentase Komulatif \\
\hline 2,57 & 1 & 2,5 & 2,7 \\
2,64 & 2 & 5,0 & 8,1 \\
2,78 & 1 & 2,5 & 10,8 \\
2,85 & 1 & 2,5 & 13,5 \\
2,92 & 7 & 17,5 & 32,4 \\
2,99 & 7 & 17,5 & 51,4 \\
3,06 & 2 & 5,0 & 56,8 \\
3,07 & 5 & 12,5 & 70,3 \\
3,13 & 1 & 2,5 & 73,0 \\
3,21 & 4 & 10,0 & 83,8 \\
3,28 & 1 & 2,5 & 86,5
\end{tabular}




\begin{tabular}{cccc}
\hline Nilai & Frekuensi & Persentase & Persentase Komulatif \\
\hline 3,35 & 1 & 2,5 & 89,2 \\
3,49 & 1 & 2,5 & 91,9 \\
3,56 & 2 & 5,0 & 97,3 \\
3,57 & 1 & 2,5 & 100,0 \\
Total & 37 & 92,5 & \\
Missing & 3 & 7.5 & \\
System & & \multicolumn{2}{c}{100.0} \\
Total & & 40 &
\end{tabular}

Berlandaskan pada tabel 4 total 37 siswa, yaitu belum ada siswa yang memperoleh nilai maksimal 4. Nilai maksimal diperoleh siswa adalah 3,57 yang didapatkan 1 siswa $(2,5 \%)$. dan nilai minimun yang didapatkan siswa 2,57 yang dicapai oleh 1 siswa atau $(2.5 \%)$. selanjutnya, ringkasan karekteristik pembagian nilai yang didapatkan siswa dilihat tabel berikut:

Tabel 5. Distribusi nilai Penerapan Model Mind Mapping

\begin{tabular}{lll}
\hline \multirow{2}{*}{$N$} & \multicolumn{1}{c}{ Valid } & \multicolumn{1}{c}{37} \\
\cline { 2 - 3 } & Missing & \multicolumn{1}{c}{3} \\
\hline Mean & 3.0568 \\
Std. Error of Mean & .03932 \\
Median & 2.9900 \\
Mode & $2.92^{\mathrm{a}}$ \\
Std. Deviation & .23918 \\
Variance & .057 \\
Range & 1.00 \\
Minimum & 2.57 \\
Maximum & 3.57 \\
Sum & 113.10 \\
\hline
\end{tabular}

Berdasarkan Tabel 5 tersebut diketahui 37 siswa yang di tes, nilai maksimum yang didapatkan 3,57 . Selanjutnya nilai minimum didapatkan anak 2,57; nilai mean adalah 3.05 ; nilai median 2,99 dan standar deviasi adalah .23918. Berlandaskan karakter nilai tersebut dapat dinyatakan kategorisasi nilai keterampilan menulis teks anekdot anekdot kelas $\mathrm{X}_{2} \mathrm{SMA}$ Muhammadiyah Kupang menggunakan model mind mapping pada kelas eksprimen.

Apabila nilai ketuntasan keterampilan menulis teks anekdot siswa dikonversi ke KKM, dapat diamati di tabel klasifikasi tingkat ketuntasan peserta didik berikut:

Tabel 6. Klasifikasi Tingkat Ketuntasan Kemampuan Menulis dengan Penerapan Model Mind Mapping

\begin{tabular}{cccc}
\hline Nilai & Frekuensi & Persentase $(\%)$ & Kategori \\
\hline Nilai 2,66 ke atas & 34 & 91,9 & Tuntas \\
Nilai di bawah 2,66 & 3 & 8,1 & Tidak tuntas \\
\hline
\end{tabular}


Berlandaskan Tabel 6 tersebut, siswa yang mendapat nilai 2,66 keatas sebanyak 34 siswa $(91,9 \%)$ dan yang mendapat nilai 2,66 ke bawah berjumlah siswa $(8,1 \%)$. Dinyatakan ketuntasan aplikasi model mind mapping pada kelas ekprimen berhasil.

Membuktikan Keefektifan Menggunakan Model Mind Mapping terhadap Menulis Teks Anekdot

Uji Normalitas

Tabel 7. Uji Normalitas Data Kelas Kontrol

Kolmogorov-

Smirnov ${ }^{\text {a }} \quad$ Shapiro-Wilk

Statistic Df Sig. Statistic df Sig.

$\begin{array}{lllllll}\text { Kontrol } & .121 & 37 & .191 & .934 & 37 & .030\end{array}$

Dari hasil uji normalitas pada Tabel 7 tersebut, didapatkan hasil kajian bahwa untuk postesst kelas $\mathrm{X}_{1}$ mempunyai $p$-value $=0.191$ dan uji-normalitas kolmogrov-smirnov dan $p$ value $=0.030$ dan uji-normalitas Shapiro-wilk. Kedua $p$-valu $>\alpha=0.05$, sehingga disimpulkan $\mathrm{H}_{1}$ diterima karena dari populasi data berdistribusi normal.

Tabel 8. uji Normalitas Data Kelas Eksperimen

\begin{tabular}{llllllll}
\hline \multirow{4}{*}{ Eksperimen } & \multicolumn{3}{c}{ Kolmogorov-Smirnova } & \multicolumn{3}{c}{ Shapiro-Wilk } \\
& Statistic & Df & Sig. & Statistic & df & Sig. \\
\cline { 2 - 8 } & .181 & 37 & .004 & .934 & 37 & .031
\end{tabular}

Berlandaskan uji normalitas pada Tabel 8 tersebut, didapatkan hasil kajian bahwa untuk postesst kelas $\mathrm{X}_{2}$ mempunyai $p$-value $=0.004$ dan uji-normalitas kolmogrov-smirnov dan $p$ value $=0.031$ dan uji-normalitas Shapiro-wilk. Kedua $p$-value $<\alpha=0.05$, tetap berdistribusi normal.

Uji Homogenitas

Pengujian terhadap hipotesis penelitian dilakukan guna memberikan pembuktian secara statistik, apakah hipotesis terterima atau tidak. Hipotesis penelitian dirumuskan dengan hipotesis nol $\left(\mathrm{H}_{0}\right)$ dan diikuti dengan $\mathrm{H}_{1}$. $\mathrm{H}_{0}$ terterima jika $p$-value>a=0,05 dan $\mathrm{H}_{1}$ terterima jika $p$-value $<a=0,05$.

Tabel 9. Uji Homogenitas Variansi

\begin{tabular}{cccccc}
\hline Levene Statistic & df1 & & df2 & & Sig. \\
\hline .471 & & 1 & & 72 & .495 \\
\hline
\end{tabular}

Berlandaskan kajian data SPSS 21 diperoleh nilai $p$-value $=0.495$ yaitu $p>a, a=0,05$. Karena nilai $p=0,0495>a=0,05$ disimpulkan bahwa variansi populasi yang sama (homogen). Nilai siswa kemudian dikaji memakai uji-t independen memakai kalkulasi homogen. 


\section{Tabel 10. Uji-T Kelas Ekperimen dan Kelas Kontrol}

\begin{tabular}{|c|c|c|c|c|c|c|c|}
\hline \multirow[b]{4}{*}{ Pair 1 postesO1- } & \multicolumn{5}{|c|}{ Paired Differences } & \multirow[b]{3}{*}{$\mathrm{t}$} & \multirow[b]{3}{*}{$\mathrm{df}$} \\
\hline & \multirow[b]{2}{*}{ Mean } & \multirow{2}{*}{$\begin{array}{c}\text { Std. } \\
\text { Deviation }\end{array}$} & \multirow{2}{*}{$\begin{array}{c}\text { Std. Error } \\
\text { Mean }\end{array}$} & \multicolumn{2}{|c|}{$\begin{array}{l}95 \% \text { Confidence } \\
\text { Interval of the } \\
\text { Difference }\end{array}$} & & \\
\hline & & & & Lower & Upper & & \\
\hline & 1.35811 & .38254 & .04447 & 1.26948 & 1.44673 & 30.541 & 73 \\
\hline
\end{tabular}

Berlandaskan data kajian uji-tabel 10 , memadankan angka $\mathrm{t}_{\text {-tabel }}$ atas $\mathrm{db}(\mathrm{df})=\mathrm{N}-1=74$ $1=73$ yaitu 1.66600 maka $t_{\text {-hitung }} 30,541>t_{\text {tabel }} 1,66600$ dan $p$-value (2-tailed) $=0.000$. Karena nilai $p$-value $<0.05$ atau $0.000>0,05$ maka hipotesis $\left(\mathrm{H}_{0}\right)$ ditolak dan hipotesis alternatif $\left(\mathrm{H}_{1}\right)$ diterima. Disimpulkan perbedaan signifikan antara keterampilan mencatat teks anekdot menggunakan model mind mapping dan model langsung dengan nilai 30,541.

\section{Pembahasan .}

Hasil tes menulis teks anekdot siswa dengan model mind Mapping berhasil dibandingkan dengan menggunakan model langsung, hal ini dapat dikonfirmasi dengan meliihat nilai rata-rata hasil posstest antara kelas eksprimen 3.05 dan kelas kontrol 2.65 dengan demikian hasil model mind mapping untuk materi ajar teks anekdot berhasil. Hal ini sejalan dengan pendapat (Sunimbar et al., 2019) model pembelajaran mind mapping adalah alternatif membantu siswa memperoleh penelaahan yang berkesan dan menarik. pendedahan siswa dengan memanfaatkan mind mapping dapat meluaskan wawasan dan inovatif bernalar bagi siswa serta tidak membuat jenuh dalam menerima matari secara menyeluruh, kemudian siswa juga belajar lebih praktis, dan mampu membuktikan, draf, hakikat, dan langkah-langkah. Mind mapping mempermudah siswa dalam mencatat materi pembelajaran dengan kreatif karena bisa menambahkan berbagai macam bentuk diksi sehingga siswa mudah mengingat materi (Cahya et al., 2019)

Siswa yang mampu mencatat teks anekdot dengan melihat struktur teks, mulai dari struktur aspek abstrkasi, orientasi, krisis, reaksi, pilihan kata, mekanik, dan koda di kelas eksprimen dengan nilai maksimum 3,57 didapatkan 1 siswa dan nilai minimum 2.57 didapatkan 1 siswa, secara keseluruhan siswa yang memperoleh nilai 2,66 ke atas 34 siswa $(91,9 \%)$ kategori tuntas, sedangkan nilai 2,66 ke bawah 3 siswa (8.1\%) kategori tidak tuntas. Selanjutnya di kelas kontrol nilai maksimum 3.00 didapatkan 2 siswa dan nilai minimum 2.28 didapatkan 4 siswa. Secara keseluruhan siswa yang mendapatkan nilai 2,66 ke atas 19 siswa $(51,3 \%)$ kategori tuntas, sedangkan nilai 2,66 ke bawah 18 siswa $(48,7 \%)$ kategori tidak tuntas.

Berlandaskan pembahasan di atas, siswa, lebih antusias dan mendapatkan kesan tersendiri dan memberi pengalaman baru serta model mind mapping menarik dan pertama di 
alami oleh siswa. untuk itu, sejalan dengan temuan yang dilakukan oleh Sunimbar dan Farid Fauzi Almu dengan judul efektivitas model pembelajaran mind mapping berbantuan media gambar materi indahnya kebersamaan untuk meningkatkan hasil belajar kognitif siswa SD MIS AI-Fitrah Oesapa, dengan subjek penelitian peserta didik 28 orang, dengan hasil posttes secara keseluruhan terdapat 24 orang atau $84 \%$ yang mencapai KKM, sedangkan 4 orang atau $14 \%$ yang tidak mencapai KKM.

Sama halnya dengan penelitian yang dilakukan oleh Andi Irma, Andi Syukri Syamsuri dan Tarman A. Arief dengan judul keefektifan teknik mind mapping berbantuan media gambar terhadap pembelajaran menulis paragraf deskripsi siswa kelas IV sekolah dasar kabupaten Pangkep. dengan nilai rata-rata 90.27 pada kelas eksprimen dengan menggunakan teknik mind mapping, sedangkan nilai rata-rata 82,33 pada kelas kontrol dengan menggunakan model langsung. Selanjutnya penelitian Netriani Syam dan Ramlah dengan judul penerapan model pembelajaran mind mapping dalam meningkatkan hasil belajar pada matapelajaran ilmu pengetahuan sosial siswa kelas IV SDN 54 kota Pare-Pare dengan subjek penelitian 26 orang dengan hasil siklus I mendapatkan $73 \%$ berada pada kategori cukup (C), sehingga melanjutkan ke siklus II, dengan hasil silklus II mendapatkan $88 \%$ kategori baik $(\mathrm{B})$.

Berlandaskan temuan dari ke tiga hasil penelitian yang relevan di atas, dapat disimpulkan bahwa model mind mapping efektif digunakan, untuk itu, sejalan dengan hasil temuan yang sajikan, tetapi ada perbedaan yaitu antara lokasi dan objek penelitian.

\section{Kesimpulan}

Berdasarkan hasil penelitian dan pembahasan dapat disimpulkan bahwa: 1) dengan memanfaatkan model langsung, masih banyak siswa yang memperoleh nilai di bawah KKM yaitu 48,7\% atau 18 siswa, 2) dengan memanfaatkan model mind mapping siswa yang mendapatkan nilai di atas KKM 91,1\% atau 34 siswa, dan 3) keterampilan menulis teks anekdot dengan efektif dengan menggunakan model mind mapping daripada model pembelajaran langsung. 


\section{Daftar Pustaka}

Cahya, D. \& Putri, D.N. (2019). Mind mapping model: Pengaruhnya terhadap hasil belajar tematik siswa sekolah dasar. Jurnal JPSD (Jurnal Pendidikan Sekolah Dasar), 6(1), $1-8$.

Irma, A., Syamsuri, A.S., \& Arief, T.A. (2020). Keefektifan teknik mind mapping berbantuan media gambar terhadap pembelajaran menulis paragraf deskripsi siswa kelas iv sekolah dasar Kabupaten Pangkep. Jurnal Profesi Keguruan, 6(1), 54-63.

Ramadhanti, D. (2017). Penerapan model kooperatif tipe CIRC dalam pembelajaran menulis narasi siswa kelas VII SMP Negeri 2 Lembah Gumanti. Gramatika, 3(1), 27-42.

Saharah, S., \& Indihadi, D. (2019). Penggunaan teknik mind mapping pada keterampilan menulis ringkasan siswa dalam pembelajaran bahasa Indonesia. Pedadidaktika: Jurnal IImiah Pendidikan Guru Sekolah Dasar, 6(1), 9-15.

Sholekah, L.A.N., \& Nuryatim, A. (2017). Budaya literasi dalam pembelajaran bahasa. Jurnal Pendidikan Bahasa dan Sastra Indonesia, 6(3), 12-16.

Situmorang, N.M.Y. (2018). Meningkatkan kemampuan menulis siswa melalui teknik guiding questions. Journal of Education Action Research, 2(2), 165-171.

Sunimbar \& Almu, F.F. (2019). Efektivitas model pembelajaran mind mapping berbantuan media gambar materi indahnya kebersamaan untuk meningkatkan hasil belajar kognitif siswa. Jurnal IImiah Pendidikan Citra Bakti, 6(2), 177-185.

Susilowati, D. (2019). Keefektifan metode mind mapping dalam pembelajaran menulis teks biografi. Jurnal Pendidikan dan Pembelajaran Bahasa Indonesia, 8(2), 136-145.

Syam, N., \& Ramlah. (2015). Penerapan model pembelajaran mind mapping dalam meningkatkan hasil belajar pada mata pelajaran ilmu pengetahuan sosial siswa kelas IV SDN 54 Kota Parepare. Publikasi Pendidikan, 5(3).

Toibah. (2019). Upaya meningkatkan kemampuan menulis teks anekdot melaui strategi pembelajaran active knowledge sharing pada peserta didik. Wahana Didaktika, 17, 195-204 